\title{
Response of slow-growing chickens to feed restriction and effects on growth performance, blood constituents and immune markers
}

\author{
Productividad, constituyentes sanguíneos y marcadores \\ inmunológicos en pollos de lento crecimiento con restricción \\ alimenticia
}

\author{
Youssef A. Attiaa*, Abd-Elhamid E. Abd-Elhamid ${ }^{\mathrm{b}}$, Manal Mustafac, Mohammed A. Al-Harthia, \\ Mai Muhammad
}

\begin{abstract}
An experiment was conducted to study the response of a slow growing chickens breed "Sinai" to feed restriction (FR) and the effects on growth performance, blood constituents and immune markers using a total number of 60 unsexed 7-d-old chicks. Chickens were housed in battery brooders during $\mathrm{d} 1$ to 35 of age and randomly distributed keeping similar initial body weight, in two FR treatment groups. During 0-6 d of age, chickens were fed ad libitum, a mash commercial diet. During d 7-14 of age, chickens were fed either $\mathbf{1 0 0}$ or $\mathbf{8 0} \%$ of the daily amount of feed consumed by the control group during the previous day. From d $\mathbf{1 5}$ to d 35 , chickens were fed ad libitum diets a mash commercial diet. At the end of the experiment, body weight gain on the FR regimen was significantly lower than that of the control group, but feed intake and feed conversion ratio (FCR) were not affected. In addition, red blood cells parameters and white blood cells traits were not negatively affected. However, hemagglutination inhibition titter for New castle disease virus, monocyte and total cholesterol were significantly decreased by FR regimen, but blood plasma albumin and immunoglobulin A significantly increased. In conclusion, slow growing chickens could tolerate $27.2 \%$ FR during the $2^{\text {nd }}$ week of age without significant differences in feed intake and FCR for the whole period, and general health status and metabolic profiles indicating a compensatory growth during 15-35 d of age although growth was in favour to the unrestricted group.
\end{abstract}

KEY WORDS: Feed restriction, Slow-growing chickens, Growth performance, Physiological traits, I mmunity.

\section{RESUMEN}

El comportamiento productivo, constituyentes sanguíneos y marcadores inmunológicos se estudiaron en pollos de la raza SI NAI de lento crecimiento bajo un régimen de restricción de alimento (RA). Se utilizaron 60 pollitos de peso similar desde la edad de 1 día hasta los 35 días. Se distribuyeron al azar en dos tratamientos de RA. De 0-6 días de edad, los animales se alimentaron con una mezcla comercial ad libitum. De 7 a 14 días de edad, se alimentaron con la misma dieta ya fuera al 100 o al $80 \%$ de consumo de alimento diario. De 15 a 35 días de edad, todas las réplicas se alimentaron con la misma dieta ad libitum. Después de los 35 días, la ganancia de peso en el régimen RA fue significativamente más baja, a pesar de que la ingesta de alimento y la tasa de conversión alimenticia (TCA) no se vieron afectados. El título de inhibición de la hemaglutinación por el virus de la enfermedad de Newcastle, los monocitos y el colesterol total fueron significativamente más bajos en el tratamiento RA. Los valores de albúmina del plasma sanguíneo y de la inmunoglobulina A fueron más altos en el tratamiento RA. Los pollos de crecimiento lento toleraron una reducción del alimento del $\mathbf{2 7 . 2 \%}$ durante la segunda semana de edad sin exhibir diferencia significativa en la ingesta del alimento y la TCA durante el tiempo de experimentación. A pesar de que el comportamiento productivo fue óptimo para el grupo control, el estatus general de salud y los perfiles metabólicos en el tratamiento de RA no se vieron afectados.

PALABRAS CLAVE: Restricción alimenticia, Pollos, Crecimiento lento, Comportamiento productivo, Características fisiológicas, Inmunidad.

\footnotetext{
Received May 4, 2016. Accepted August 26, 2016.

${ }^{a}$ Arid Land Agriculture Department, Faculty of Meteorology, Environment and Arid Land Agriculture, King Abdulaziz University, P.O. Box 80208, Jeddah 21589, Saudi Arabia.

${ }^{\mathrm{b}}$ Animal and Poultry Production Dpt. Faculty of Agriculture. Damanhour University, Egypt.

'Plant Protection Dpt. Faculty of Agriculture. Damanhour University, Egypt.

Corresponding author: yaattia@kau.edu.sa
} 


\section{INTRODUCTION}

In the tropics, where grains and oilseeds are scarce or expensive, it may be appropriate to take advantage of catch-up growth and even incorporate it into normal production systems. Animals may respond differently to feed restriction (FR) during re-alimentation period when FR is removed, thus resulted in compensatory growth and reached the growth of unrestricted animals ${ }^{(1)}$.

Extensive studies in poultry, particularly in broiler chickens, demonstrated inconsistency in the compensatory growth due to genetic factors, FR period, duration and verity of FR, the feeding regimen during the re-alimentation period ${ }^{(2,3,4)}$. In literature, FR was reported to improve feed utilization, decrease fat deposition and decrease leg problems in broiler chickens ${ }^{(5)}$. However, it seems that there is a critical time in broilers from hatch to $21 \mathrm{~d}$ of age, when nutritional manipulation can cause a catch-up growth. Fed-restricted broilers displayed similar growth at market as the FR for 4and 6-d and the control group showed similar postrestriction growth and market weights ${ }^{(6)}$. The FR for $6 \mathrm{~h}$ of feeding mash diet increased growth ${ }^{(7)}$. The catch-up growth of slow-growing/native chicks to cope with early FR are interesting as shortage of feeds is a problem in many developing countries. On the other hand, studies on slow-growing chicks rare, however, they may have higher adoption to FR because of lower growth and less nutrient requirements than fast-growing chicks. Therefore, this research was conducted to expand the knowledge of catch-up growth in slow-growing chicks in terms of productive performance, physiological traits, and immunity.

\section{MATERIAL AND METHODS}

\section{Chickens, diet and experimental design}

A total of 60 unsexed chicks of native chickens' breeds (Sinai) were used in this study. Chicks were randomly distributed into two feed restriction treatment groups keeping similar body weight at $7 \mathrm{~d}$ of age. Each treatment was replicated five times of six unsexed chicks each. During 0-6 d of age, chickens were fed ad libitum commercial diets containing adequate nutrients for growth, $22.92 \%$ crude protein (CP) and $12.72 \mathrm{MJ} \mathrm{ME} / \mathrm{kg}$ diet with adequate amino acids, minerals and vitamins. During d 7-14 of age, chicks were fed either 100 or $80 \%$ of the daily amount of feed consumed by the control group during the previous day. From d 15 to 35, chickens were fed ad libitum diets containing $21.1 \% \mathrm{CP}$ and $12.98 \mathrm{MJ} \mathrm{ME} / \mathrm{kg}$ until the end of the experiment.

\section{Husbandry}

Chicks were housed in battery brooders during d 1 to 35 of age and vaccinated with Hitchiner + IB + Gambaro, Influenza H5 N2, Colon30, Gambaro 123, Colon79 and Lasota at d 7, 9, 10, 16, 20 and 30 of age. During the experiment, the ambient temperature and the relative humidity were $31.4 \pm$ $4{ }^{\circ} \mathrm{C}$ and $44.9 \pm 6 \%$, respectively; with $24 \mathrm{~h}$ light in day one, and 23: 1 light-dark cycle during d 2 to 35 of age.

\section{Measurements}

Chickens were weighed $(\mathrm{g})$ on replicate basis at d 7, 14, 28, and 35 of age. Chicks were weighed in the morning before offering feed, while body weight gains were predicated by deducting body weight at end of each period from the initial body weight at the same period per replicate. Feed intake per replicate was recorded during the periods 7-14, 7-28 and $7-35 \mathrm{~d}$ of age. Feed conversion ratio $(\mathrm{kg}$ feed $/ \mathrm{kg}$ gain) per replicate was calculated as the units $(\mathrm{g})$ of feeds needed to yield one unit $(\mathrm{g})$ of growth during the 7-14, 7-28 and 7-35 d of age. Sunvival rate was presented as number of lived chickens at the termination of the experiment in each group as relative to the initial number of chicks in each treatment.

At $35 \mathrm{~d}$ of age, six chickens comprising three males and three females representing all treatment replicates were selected randomly from each treatment, weighed after overnight fasting, slaughtered according to the Islamic method, bleed, and feather picked. The lymphoid organs thymus, bursa of Fabricius and spleen, were separated and individually weighed and expressed as relative to live body weight. At 14 and $35 \mathrm{~d}$ of age, blood samples ( $n=6$ chickens per treatment representing all 
treatment replicates at each age, which were selected randomly) were taken from the wing-vein of chickens before access to feed and water. The blood samples were collected in two clean dry centrifuge tubes with or without an anti-coagulant (heparin). The one with heparin was used for determination of blood hematology, phagocytic activity (PA) and phagocytic index (PI). Then the tubes were centrifuged at 3,000 rpm for $20 \mathrm{~min}$ to clearly separate serum and plasma. Serum and plasma were stored at $-20{ }^{\circ} \mathrm{C}$ until analysis. Blood biochemical constituents were determined using commercial diagnostic kits purchased from Diamond Diagnostic company (23 EL-Montazah St. Heliopolis, Cairo, Egypt), while blood hematology were performed as cited by Attia et $a^{(8,9)}$. Plasma tri iodo threonine $\left(T_{3}\right)$ and thyroxine $\left(T_{4}\right)$ were determined according to the method of Young et $a l^{10)}$. Phagocytic activity and phagocytic index were determined as cited by Kawahara et $a^{(11)}$. The serum antibody against New Castle disease virus (NDV) and avian influenza virus (AIV) was done via haemagglutination inhibition $(\mathrm{HI})$ test $^{(12,13)}$. The antibody titer for infectious bursa disease virus (IBDV) was carried out according to Cosgrove ${ }^{(14)}$. Bactericidal activity (BacA) in serum was according to Rainger et $a{ }^{(15)}$.

\section{Statistical analyses}

Analysis of variance was done using one-way ANOVA of $S A S{ }^{(16)}$ for growth performance and two-ways for traits containing two factors such as feed restriction and sex or age of chickens. All the percentages were transformed to $\log ^{10}$ to normalize data distribution. Mean difference at $P \leq 0.05$ was tested using the Student Newman Keuls test ${ }^{(16)}$. Survival rate was analyzed using chi-square test.

\section{RESULTS AND DISCUSSION}

\section{Growth performance}

Table 1 indicates the effect of FR on growth, feed intake and FCR and survival rate. FR significantly decreased growth during d 7-14, 7-28 and $7-35$ of age. It was found that $27.2 \%$ FR during the $2^{\text {nd }}$ wk of age had long term negative effect on growth of Sanai chickens (for example, 31.6, 14.6 and $11.7 \%$ during 7-14, 7-28 and 7-35 d of age, respectively). These indicated a compensatory growth during 14-28 and 14-35 d of age without induction of complete recovery at the termination of the experiment (88.3\%). The decreased growth of FR group during the FR period coincided with lowered nutrients intake ( $72.8 \%$ ), which account for $86 \%$ of the decrease in growth. Similar to the present results, growth of broilers was significantly higher for the control group than those of the FR groups $^{(7,17,18)}$. However, a compensatory growth in broilers following FR was reported ${ }^{(1,5,7)}$. Moreover, broilers feed restricted grow faster and were heavier at market age than the control group, while group on the 4- and 6-d FR and the control chickens have similar weight at marketing(6). The published results indicated that most weight loss during early FR in chickens could be compensated by $20-25 \mathrm{~d}$ of the

Table 1. Effect of feed restriction regimen on growth performance of native strain during 7-35 $\mathrm{d}$ of age $(\mathrm{g})$

\begin{tabular}{|c|c|c|c|c|c|c|c|c|c|c|}
\hline \multirow{2}{*}{ Treatment } & \multicolumn{3}{|c|}{ Body weight gain } & \multicolumn{3}{|c|}{ Feed intake } & \multicolumn{3}{|c|}{ Feed conversion ratio, feed / gain } & \multirow{2}{*}{$\begin{array}{l}\text { Survival } \\
\text { rate (\%) }\end{array}$} \\
\hline & $\begin{array}{c}\text { Days } \\
7-14 \\
\end{array}$ & $\begin{array}{l}\text { Days } \\
7-28 \\
\end{array}$ & $\begin{array}{c}\text { Days } \\
7-35 \\
\end{array}$ & $\begin{array}{c}\text { Days } \\
7-14 \\
\end{array}$ & $\begin{array}{c}\text { Days } \\
7-28\end{array}$ & $\begin{array}{c}\text { Days } \\
7-35\end{array}$ & $\begin{array}{l}\text { Days } \\
7-14\end{array}$ & $\begin{array}{c}\text { Days } \\
7-28\end{array}$ & $\begin{array}{c}\text { Days } \\
7-35\end{array}$ & \\
\hline \multicolumn{11}{|c|}{ Effect of feed restriction regimen ${ }^{1}$} \\
\hline Control & $38^{a}$ & $205^{a}$ & $230^{\mathrm{a}}$ & $92^{\mathrm{a}}$ & 550 & 701 & 2.421 & $2.683^{b}$ & 3.047 & 90.0 \\
\hline $\begin{array}{l}\text { Feed } \\
\text { restriction }\end{array}$ & $26^{b}$ & $175^{b}$ & $203^{b}$ & $67^{b}$ & 562 & 716 & 2.577 & $3.211^{\mathrm{a}}$ & 3.527 & 87.7 \\
\hline SEM & 2.04 & 9.90 & 8.69 & 6.85 & 20.32 & 37.70 & 0.123 & 0.109 & 0.148 & 2.13 \\
\hline \multicolumn{11}{|c|}{ Probability level } \\
\hline $\mathrm{FR}$ & 0.001 & 0.05 & 0.041 & 0.046 & 0.615 & 0.743 & 0.40 & 0.01 & 0.061 & 0.667 \\
\hline
\end{tabular}

${ }^{1}=$ Number of observation were 5 replicates of 6 unsexed chicks each/treatment; SEM= standard error of mean, FR= Feed restriction.

a, b Differences among means within a column within each factor not sharing similar superscripts are significant $(P<0.05)$. 
re-feeding period ${ }^{(19)}$. Moreover, FR at $75 \%$ or $50 \%$ for 7 and $14 \mathrm{~d}$ period, respectively did not significantly influence the final body weight of broilers at $42 \mathrm{~d}$ of age ${ }^{(20)}$. These contradictory results about the effect of FR on the growth could be due to the duration and intensity of FR and/or strain of chickens.

Feed intake of FR group was decreased during 7-14 $\mathrm{d}$ of age and there was a significant difference ( $P=0.046)$ compared to the control. The realimented chickens consumed more feed by $6.6 \%$ during d 14-35 of age; this indicates an attempt to compensate for the decrease $(27.2 \%)$ in feed intake that occurred during FR period. Similarly, feed intake at $21 \mathrm{~d}$ of age was significantly decreased for feedrestricted chicks ${ }^{(2)}$. In addition, the feed-restricted chicks and the control groups at $63 \mathrm{~d}$ of age consumed similar amount of feed. In addition, FR did not affect feed intake for the whole period ${ }^{(21)}$.

Feed conversion was not affected by FR treatments during the period 7-14 and 7-35 of age, but significantly impaired by $19.7 \%$ compared to the control group, during d 7-28 of age. In concert with the current results, there was no significant effect of FR regimen on the body weight, feed intake, and FCR in the whole period ${ }^{(21,22)}$. However, an improvement in FCR due to increased growth and decreased feed intake via FR was observed ${ }^{(7)}$. Others, observed that feed efficiency for maintaining body weight may be affected by the plan of nutrition, but this was confounded by nutritional regimen and duration, growth, strain and age of chickens ${ }^{(23)}$.

Survival rate was similar among the experimental groups, showing that FR had no harmful effect and correlate to the findings of other experiments $s^{(1,5,20)}$. However, published results indicated that FR increased survival rate due to less sudden death, ascites and skeletal disorders ${ }^{(24,25)}$.

\section{Lymphoid organs, antioxidant status and immune markers}

FR regimen did not have significant influence on lymphoid organs (Table 2), total antioxidant capacity (TAC), malondialdehyde (MDA), I mmunoglobulin M (IgM), Immunoglobulin G (IgG), HIIBD, HIAl, Lysosome activity (LyzA), BacA, PA and PI, but immunoglobulin A (IgA) significantly increased by $3.9 \%$ compared to the control (Table 3). On the other hand, humeral immunity HINDV decreased by $24.6 \%$ and non-specific immune components such

Table 2. Effect of feed restriction regimen and/or sex of chickens on the absolute and relative weight of thymus, bursa and spleen at $35 \mathrm{~d}$ of age

\begin{tabular}{|c|c|c|c|c|c|c|c|}
\hline \multicolumn{2}{|l|}{ Treatment } & Thymus (g) & Thymus (\%) & Bursa (g) & Bursa (\%) & Spleen $(\mathrm{g})$ & Spleen (\%) \\
\hline \multicolumn{8}{|c|}{ Effect of feed restriction regimen ${ }^{1}$} \\
\hline \multicolumn{2}{|l|}{ Control (C) } & 1.833 & 0.621 & 0.875 & 0.291 & 1.113 & 0.378 \\
\hline \multicolumn{2}{|c|}{ Feed restriction (FR) } & 1.728 & 0.583 & 1.000 & 0.297 & 1.210 & 0.397 \\
\hline \multicolumn{8}{|c|}{ Effect of sex of chickens ${ }^{2}$} \\
\hline \multicolumn{2}{|l|}{ Male } & 1.827 & 0.574 & 1.153 & 0.349 & 1.293 & 0.406 \\
\hline \multicolumn{2}{|l|}{ Female } & 1.716 & 0.640 & 0.545 & 0.197 & 0.978 & 0.361 \\
\hline \multicolumn{8}{|c|}{ Interaction between FR regimen and sex ${ }^{3}$} \\
\hline \multirow[t]{2}{*}{ C } & Male & 1.807 & 0.580 & 1.240 & 0.401 & 1.100 & 0.355 \\
\hline & Female & 1.860 & 0.661 & 0.510 & 0.180 & 1.127 & 0.401 \\
\hline \multirow[t]{2}{*}{ FR } & Male & 1.842 & 0.570 & 1.088 & 0.311 & 1.438 & 0.444 \\
\hline & Female & 1.500 & 0.609 & 0.650 & 0.245 & 0.755 & 0.302 \\
\hline \multicolumn{2}{|c|}{ SEM } & 0.324 & 0.092 & 0.467 & 0.108 & 0.236 & 0.062 \\
\hline \multicolumn{8}{|c|}{ Probability level } \\
\hline \multicolumn{2}{|c|}{ Feed restriction } & 0.636 & 0.745 & 0.991 & 0.917 & 0.945 & 0.939 \\
\hline \multicolumn{2}{|l|}{ Sex } & 0.672 & 0.535 & 0.295 & 0.268 & 0.208 & 0.463 \\
\hline \multicolumn{2}{|l|}{ Interaction } & 0.565 & 0.827 & 0.785 & 0.535 & 0.177 & 0.173 \\
\hline
\end{tabular}

$1=$ number of observation were 6 chickens/treatment. ${ }^{2}=$ number of observation were 6 chickens/sex, ${ }^{3=}$ number of observation were 3 chickens/treatment; SEM=standard error of mean. 
Table 3. Effect of feed restriction regimen and/or age of chickens on antioxidant status and immune markers

\begin{tabular}{|c|c|c|c|c|c|c|c|c|c|c|c|c|c|}
\hline \multicolumn{2}{|c|}{ Treatment } & $\begin{array}{c}\text { TAC } \\
(\mu \mathrm{mol} / \mathrm{L})\end{array}$ & $\begin{array}{c}\mathrm{MDA} \\
(\mu \mathrm{M} / \mathrm{L})\end{array}$ & $\lg \mathrm{A}$ & $\lg \mathrm{M}$ & $\lg G$ & $\begin{array}{l}\text { HINDV, } \\
\text { Log2 }\end{array}$ & $\begin{array}{l}\text { HIIBD, } \\
\text { Log2 }\end{array}$ & $\begin{array}{l}\text { HIAl, } \\
\log 2\end{array}$ & $\begin{array}{l}\text { LyzA } \\
\text { IU }\end{array}$ & $\begin{array}{c}\text { BacA } \\
(\%)\end{array}$ & $\begin{array}{l}\text { Phagocytes } \\
\text { activity } \\
\text { (\%) }\end{array}$ & $\begin{array}{l}\text { Phagocytes } \\
\text { index } \\
(\%)\end{array}$ \\
\hline \multicolumn{14}{|c|}{ Effect of feed restriction regimen ${ }^{1}$} \\
\hline \multicolumn{2}{|c|}{ Control } & 424.3 & 0.997 & $66.7^{\mathrm{b}}$ & 221.8 & 972.9 & $3.42^{\mathrm{a}}$ & 2.75 & 2.42 & 0.090 & 36.8 & 21.2 & 1.55 \\
\hline \multicolumn{2}{|c|}{$\begin{array}{c}\text { Feed } \\
\text { restriction }\end{array}$} & 427.9 & 1.039 & $69.3^{\mathrm{a}}$ & 224.5 & 973.2 & $2.58^{b}$ & 3.17 & 2.00 & 0.088 & 36.8 & 21.1 & 1.64 \\
\hline \multicolumn{14}{|c|}{ Effect of age ${ }^{2}$} \\
\hline \multicolumn{2}{|c|}{14} & $428.5^{\mathrm{a}}$ & 1.096 & $71.2^{\mathrm{a}}$ & 222.4 & $970.8^{b}$ & 2.67 & $2.67^{\mathrm{b}}$ & 2.08 & 0.088 & 36.5 & 20.7 & 1.63 \\
\hline \multicolumn{2}{|c|}{35} & $423.7^{\mathrm{b}}$ & 0.940 & $64.8^{\mathrm{b}}$ & 223.9 & $975.3^{\mathrm{a}}$ & 3.33 & $3.25^{\mathrm{a}}$ & 2.33 & 0.090 & 37.0 & 21.6 & 1.57 \\
\hline \multicolumn{14}{|c|}{ Interaction between FR regimen and age of chickens ${ }^{3}$} \\
\hline \multirow{2}{*}{ C } & 14 & $424.2^{\mathrm{b}}$ & 1.020 & $68.7^{\mathrm{b}}$ & 219.0 & $973.8^{\mathrm{ab}}$ & 3.00 & 2.67 & 2.17 & $0.107^{\mathrm{a}}$ & 37.2 & 20.2 & 1.52 \\
\hline & 35 & $424.3^{\mathrm{b}}$ & 0.973 & $64.7^{\circ}$ & 224.7 & $972.0^{\mathrm{bc}}$ & 3.83 & 2.83 & 2.67 & $0.073^{b}$ & 36.3 & 22.2 & 1.58 \\
\hline \multirow{2}{*}{ FR } & 14 & $432.8^{a}$ & 1.172 & $73.7^{\mathrm{a}}$ & 225.8 & $967.7 \mathrm{c}$ & 2.33 & 2.67 & 2.00 & $0.068^{b}$ & 35.8 & 21.2 & 1.73 \\
\hline & 35 & $423.0^{\mathrm{b}}$ & 0.907 & $64.8^{\mathrm{c}}$ & 223.2 & $978.7^{\mathrm{a}}$ & 2.83 & 3.67 & 2.00 & $0.107^{\mathrm{a}}$ & 37.7 & 21.0 & 1.55 \\
\hline \multicolumn{2}{|c|}{ SEM } & 1.833 & 0.077 & 0.926 & 2.131 & 1.887 & 0.354 & 0.271 & 0.318 & 0.006 & 0.732 & 0.622 & 0.084 \\
\hline \multicolumn{14}{|c|}{ Probability level } \\
\hline \multicolumn{2}{|c|}{ FR } & 0.059 & 0.587 & 0.011 & 0.225 & 0.896 & 0.029 & 0.140 & 0.206 & 0.693 & 1.000 & 0.895 & 0.288 \\
\hline \multicolumn{2}{|c|}{ Age } & 0.016 & 0.057 & 0.0001 & 0.490 & 0.025 & 0.074 & 0.044 & 0.442 & 0.693 & 0.503 & 0.156 & 0.495 \\
\hline \multicolumn{2}{|c|}{ Interaction } & 0.013 & 0.172 & 0.017 & 0.065 & 0.003 & 0.643 & 0.140 & 0.442 & 0.0001 & 0.084 & 0.097 & 0.152 \\
\hline
\end{tabular}

TAC=Total antioxidant capacity; MAD= Malondialdehyde; IgA= Immunoglobulin A; IgM=Immunoglobulin MM IgG=Immunoglobulin G; HINDV= Newcastle disease; HIIBD= Infection bursa disease; HIAI=Avian influenza; lyzA=Lysosome activity; BacatA= Bactrio activity; SEM= standard error of mean.

${ }^{1}=$ Number of observation were 12 chicks/treatment, ${ }^{2}=$ Number of observation were 12 chicks/age, ${ }^{3}=$ Number of observation were 6 chicks/treatment/age.

a,b,c Differences among means within a column within each factor not sharing similar superscripts are significant $(P<0.05)$.

as monocyte (macrophages; Table 4) decreased by $13.6 \%$. The increase in IgA of the FR groups indicated the stressful condition of chickens exposed to FR regimen undergo as proved by the low antibody titter to NDV and low growth at the end of the experiment. IgA involves in mucosal surface protection $^{(26)}$, and prevents immunoglobulin degradation by proteolytic enzymes, thus improve its survival in the harsh gut environment and protection against the multiplication of microbes in body secretions ${ }^{(27)}$. IgA can also prevent inflammatory influences of other immunoglobulin ${ }^{(28)}$.

Age of chickens had a significant effect on TAC and IgA showing a significant decrease at $35 \mathrm{~d}$ of age compared to $14 \mathrm{~d}$ of age; but, IgG and HIIBD significantly increased. FR increased TAC and IgA of FR group at $14 \mathrm{~d}$ of age, but IgG and LysA were decreased. In addition, 35-d-old FR group increased IgG and LysA, revealing the positive impact of realimentation on immune response of chickens ${ }^{(29,30)}$. Nonetheless, IgG of broiler chickens at 14 and $35 \mathrm{~d}$ of age were not significantly influenced by either quantitative FR regimen(31), qualitative FR regimen or one-third reduction in amino acids, protein and energy(32). However, there were no significant effects of FR on immune structure and function of the gut, including bursa mass, spleen mass, and total IgA content of intestinal flush samples ${ }^{(33)}$.

There was significant interaction between FR regimen and age of chicks on only TAC, IgA, IgG and LysA. The results indicate that TAC and IgA of FR group at $14 \mathrm{~d}$ of age was significantly greater than those of the other groups, but IgG and LysA were lower than those of the control group at $\mathrm{d} 14$ and FR group at d 35 of age. On the other hand, IgG and LysA of 35-d-old FR group were higher than the control at the same age. In accordance with the current results, immune response against NDV and IBD at $30^{\text {th }} \mathrm{d}$ of age was found to be lower in the FR group than the control group ${ }^{(34)}$. In addition, FR at 75 and $50 \%$ of daily feed intake during 7-14 or 7$21 \mathrm{~d}$ of age did not affect absolute and relative 
weight of spleen and thymus, but groups on FR at 75 and $50 \%$ for $7 \mathrm{~d}$ significantly increased Fabricius bursa compared to their counterparts groups ${ }^{(20)}$. Similarly, nutritional status had a crucial role in immunity and under-nutrition can negatively affect immune function ${ }^{(29,31)}$.

\section{Blood components}

Table 4 shows the effect of FR regimen and age of chicks on the parameters of white and red blood cells. Obviously, FR regimen had no significant effect on most of white blood cell parameters except for monocyte, showing that lower value of FR group than that of the control group, while there was a trend for heterophile to increase ( $P \leq 0.068)$.

Age of chickens had a significant influence on white blood cells (WBC) count and monocyte, showing higher WBC of 35-d old than those of $14 \mathrm{~d}$ old, but monocyte was lower. There were significant interactions between FR regimen and chickens age in the lymphocyte, herterophile and heterophile/ lymphocyte ratio. The results show that $14 \mathrm{~d}$-old chickens on FR regimen showed lower WBC count $(P \leq 0.092)$ than the other groups, but higher lymphocyte $(P \leq 0.004)$ than the $14 \mathrm{~d}$-old control group and $35 \mathrm{~d}$-old FR group. Chickens ( $35 \mathrm{~d}$-old) on the control treatment exhibited significantly lower heterophile than those of the other groups, and lower heterophile/lymphocyte ratio than those of the control group at $14 \mathrm{~d}$ of age and FR group at $35 \mathrm{~d}$ of age. At the end of FR period ( $14 \mathrm{~d}$ of age), WBC count decreased, but lymphocyte (cell-mediated immunity) increased compared to $35 \mathrm{~d}$-old FR group. These results indicate that though WBC count decreased at the end of FR period, chickens are compensated with increasing cell mediated immunity and had similar non-specific immune component (heterophile) and stress index heterophile/lymphocyte ratio. However, at $35 \mathrm{~d}$ of age, FR groups exhibited greater stress than the control group at the same age; this can be attributed to the significant decrease in cell-mediated immunity (lymphocyte). These changes in WBC count, lymphocyte and heterophile/lymphocyte ratio indicate that slow-growing chickens adapted to FR

Table 4. Effect of feed restriction regimen and/or age of chickens on characteristics of white and red blood cells

\begin{tabular}{|c|c|c|c|c|c|c|c|c|c|}
\hline \multicolumn{2}{|c|}{ Treatment } & \multicolumn{5}{|c|}{ White blood cell parameters } & \multicolumn{3}{|c|}{ Red blood cell parameters } \\
\hline & & $\begin{array}{l}\text { WBC } \\
\left(10^{3 / / I}\right)\end{array}$ & $\begin{array}{l}\text { Lymphocyte } \\
\text { (\%) }\end{array}$ & $\begin{array}{c}\text { Monocyte } \\
(\%)\end{array}$ & $\begin{array}{c}\text { Heterophile } \\
(\%)\end{array}$ & HLR & $\begin{array}{l}\mathrm{Hgb} \\
(\mathrm{mg} / \mathrm{l})\end{array}$ & $\begin{array}{l}\text { PCV } \\
(\%)\end{array}$ & $\begin{array}{c}\text { MCV } \\
\text { (fl/cell) }\end{array}$ \\
\hline \multicolumn{10}{|c|}{ Effect of feed restriction regimen ${ }^{1}$} \\
\hline \multicolumn{2}{|c|}{ Control (C) } & 24.5 & 44.6 & $11.7^{a}$ & 31.5 & 0.709 & 10.67 & 32.5 & 205.5 \\
\hline \multicolumn{2}{|c|}{ Feed restriction (FR) } & 23.2 & 44.5 & $10.3^{b}$ & 33.2 & 0.748 & 10.83 & 32.6 & 194.8 \\
\hline \multicolumn{10}{|c|}{ Effect of age $^{2}$} \\
\hline \multicolumn{2}{|l|}{$14 \mathrm{~d}$-old } & $22.9^{b}$ & 45.0 & $32.9^{\mathrm{a}}$ & 0.733 & 11.5 & 10.75 & 32.5 & 197.7 \\
\hline \multicolumn{2}{|l|}{35 d-old } & $24.8^{a}$ & 44.1 & $31.8^{b}$ & 0.724 & 11.1 & 10.75 & 32.6 & 202.6 \\
\hline \multicolumn{10}{|c|}{ Interaction between FR regimen and sex ${ }^{3}$} \\
\hline \multirow[b]{2}{*}{ C } & 14 & 24.2 & $44.0^{\mathrm{bc}}$ & 10.3 & $33.0^{a}$ & $0.752^{\mathrm{a}}$ & $10.17^{b}$ & $31.0^{\mathrm{b}}$ & $195.1^{\mathrm{ab}}$ \\
\hline & 35 & 24.8 & $45.2^{\mathrm{ab}}$ & 13.0 & $30.0^{\mathrm{b}}$ & $0.666^{b}$ & $11.17^{\mathrm{ab}}$ & $34.0^{\mathrm{a}}$ & $216.0^{\mathrm{a}}$ \\
\hline \multirow[b]{2}{*}{ FR } & 14 & 21.7 & $46.0^{a}$ & 9.2 & $32.8^{\mathrm{a}}$ & $0.714^{a b}$ & $11.33^{\mathrm{a}}$ & $34.0^{\mathrm{a}}$ & $200.3^{a b}$ \\
\hline & 35 & 24.7 & $43.0^{c}$ & 11.5 & $33.5^{a}$ & $0.782^{\mathrm{a}}$ & $10.33^{a b}$ & $31.2^{\mathrm{ab}}$ & $189.2^{b}$ \\
\hline \multicolumn{2}{|l|}{ SEM } & 0.660 & 0.638 & 0.361 & 0.828 & 0.028 & 0.346 & 0.978 & 7.467 \\
\hline \multicolumn{10}{|c|}{ Probability level } \\
\hline \multicolumn{2}{|l|}{ FR } & 0.057 & 0.897 & 0.002 & 0.068 & 0.169 & 0.635 & 0.933 & 0.165 \\
\hline \multirow{2}{*}{\multicolumn{2}{|c|}{ Age }} & 0.012 & 0.166 & 0.001 & 0.174 & 0.752 & 1.000 & 0.933 & 0.521 \\
\hline & & 0.092 & 0.004 & 0.649 & 0.038 & 0.011 & 0.009 & 0.007 & 0.044 \\
\hline
\end{tabular}

WBC= white blood cells; HLR= Heterophile/Lymphocyte ratio; Hgb= Hemoglobin; PCV= Packed cell volume; MCV= Mean corpuscular values; SEM= Standard error of mean.

$1=$ Number of observation were 12 chicks/treatment, ${ }^{2}=$ Number of observation were 12 chicks/age, ${ }^{3=}$ Number of observation were 6 chicks/treatment/age.

a,b,c Differences among means within a column within each factor not sharing similar superscripts are significant $(P<0.05)$. 
regimen by modifying different immune components. The decrease in IgG, HINDV and HIAI at the end of FR period and at the end of the realimentation period confirm this hypothesis. During the first 3 wk of age, a transition from maternal immunity to humoral immunity and development and maturation of immune system occurred ${ }^{(35)}$. These changes in immunoglobulins IgG and antibody against NDV, IBDV and Al proved the improvement in the defence system with increasing age of chickens. However, the decrease of TAC with advanced age of chickens may indicate the use of antioxidants for antibody production during the transient period. Similarly, antibody to NDV of ad libitum fed chickens declined with duration of stress ${ }^{(36)}$. H-L ratio and tonic immobility duration were higher at $41 \mathrm{~d}$ of age in broilers fed ad libitum than those FR for $4 \mathrm{~h}$ per day from 7 to $21 \mathrm{~d}$ and fed ad libitum thereafter ${ }^{(23)}$, and FR induced stress on WBC during only the FR period ${ }^{(37,38)}$.

It was demonstrated that FR regimen and age of chickens did not significantly affect $\mathrm{Hgb}, \mathrm{PCV}$ and MCV. However, there were significant interactions between FR regimen and chickens' age on the Hgb,
PCV and MCV. It was found that $14 \mathrm{~d}$-old chickens on FR showed significantly higher Hgb and PCV than its counterpart group on the control regimen. However, MCV of the control group at $35 \mathrm{~d}$ of age was significantly higher than that of the FR group at the same age. Moderate FR regimen (27.2\%) during the $2^{\text {nd }}$ wk of age had no deleterious effect on blood haematology, as difference within FR groups was not significant between 14 and $35 \mathrm{~d}$ old chickens. Results on the effects of FR regimen on blood haematology are rare in the literature. In concert with the current results, haematological values were not affected by FR or sex $(P>0.05)^{(17)}$. In addition, feed removal for 3 or $6 \mathrm{~h}$ a day during 5-37 d of age did not significantly affected the PCV and RBC, but feed removal for $6 \mathrm{~h}$ significantly increased $\mathrm{Hgb}$ compared to the control and $3 \mathrm{~h}$ FR groups ${ }^{(39)}$.

\section{Metabolic profiles}

Table 5 reveals the influences of FR regimen and age of chicks on blood plasma biochemical constituents. It was found that FR had a significant effect on only plasma albumin and total cholesterol, but the effect on plasma total protein, globulin, $T_{3}$,

Table 5. Effect of feed restriction regimen and/or age of chickens on blood plasma biochemical traits

\begin{tabular}{|c|c|c|c|c|c|c|c|c|c|c|}
\hline \multicolumn{2}{|c|}{ Treatment } & $\begin{array}{l}\text { Total protein } \\
\text { (g/dl) }\end{array}$ & $\begin{array}{l}\text { Albumin } \\
\text { (g/dl) }\end{array}$ & $\begin{array}{c}\text { Globulin } \\
\text { (g/dl) }\end{array}$ & $\begin{array}{c}\text { Cholesterol } \\
\text { (mg/dl) }\end{array}$ & $\begin{array}{c}\mathrm{T}_{3} \\
(\mathrm{ng} / \mathrm{ml})\end{array}$ & $\begin{array}{c}\mathrm{T}_{4} \\
(\mathrm{ng} / \mathrm{ml})\end{array}$ & $T_{3} / T_{4}$ & $\begin{array}{c}\text { Glucose } \\
\mathrm{mg} / \mathrm{dl}\end{array}$ & $\begin{array}{c}\text { Cortisone } \\
\mathrm{mg} / \mathrm{dl}\end{array}$ \\
\hline \multicolumn{11}{|c|}{ Effect of feed restriction regimen ${ }^{1}$} \\
\hline \multicolumn{2}{|c|}{ Control } & 5.62 & $3.21^{b}$ & 2.41 & $218.8^{a}$ & 2.44 & 1.35 & 1.83 & 213.3 & 3.88 \\
\hline \multicolumn{2}{|c|}{ Feed restriction } & 5.64 & $3.37^{a}$ & 2.27 & $211.7^{b}$ & 2.51 & 1.43 & 1.80 & 208.9 & 4.05 \\
\hline \multicolumn{11}{|c|}{ Effect of age $^{2}$} \\
\hline \multicolumn{2}{|c|}{$14 \mathrm{~d}$-old } & $5.75^{\mathrm{a}}$ & $3.07^{\mathrm{b}}$ & $2.68^{\mathrm{a}}$ & 214.9 & $2.58^{\mathrm{a}}$ & 1.38 & 1.88 & $222.5^{\mathrm{a}}$ & 3.94 \\
\hline \multicolumn{2}{|c|}{$35 \mathrm{~d}$-old } & $5.51^{b}$ & $3.52^{\mathrm{a}}$ & $1.99^{b}$ & 215.5 & $2.38^{b}$ & 1.39 & 1.75 & $199.8^{b}$ & 3.98 \\
\hline \multicolumn{11}{|c|}{ Interaction between FR regimen and age of chickens 3} \\
\hline \multirow{2}{*}{ C } & 14 & $5.88^{a}$ & $2.83^{c}$ & $3.03^{\mathrm{a}}$ & 219.0 & 2.53 & 1.40 & 1.82 & 223.7 & 3.88 \\
\hline & 35 & $5.35^{c}$ & $3.58^{a}$ & $1.77^{c}$ & 218.5 & 2.35 & 1.30 & 1.84 & 203.0 & 3.87 \\
\hline \multirow{2}{*}{ FR } & 14 & $5.62^{b}$ & $3.30^{\mathrm{b}}$ & $2.32^{b}$ & 210.8 & 2.62 & 1.37 & 1.94 & 221.3 & 4.00 \\
\hline & 35 & $5.67 a b$ & $3.45^{\mathrm{ab}}$ & $2.22^{b}$ & 212.5 & 2.40 & 1.48 & 1.66 & 196.5 & 4.10 \\
\hline & & 0.090 & 0.075 & 0.135 & 1.638 & 0.087 & 0.070 & 0.107 & 3.749 & 0.102 \\
\hline \multicolumn{11}{|c|}{ Probability level } \\
\hline \multicolumn{2}{|l|}{ FR } & 0.783 & 0.038 & 0.335 & 0.0003 & 0.455 & 0.294 & 0.817 & 0.253 & 0.101 \\
\hline \multicolumn{2}{|c|}{ Age } & 0.014 & 0.0001 & 0.001 & 0.725 & 0.033 & 0.906 & 0.243 & 0.0001 & 0.686 \\
\hline \multicolumn{2}{|c|}{$P$ value } & 0.004 & 0.001 & 0.0003 & 0.516 & 0.851 & 0.135 & 0.185 & 0.585 & 0.573 \\
\hline
\end{tabular}

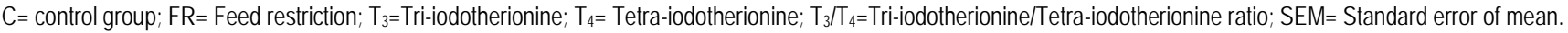
$1=$ Number of observation were 12 chicks/treatment, ${ }^{2}=$ Number of observation were 12 chicks/age, ${ }^{3=}$ Number of observation were 6 chicks/treatment/age.

a,b,c Differences among means within a column within each factor not sharing similar superscripts are significant $(P<0.05)$. 
$T_{4}, T_{3} / T_{4}$, glucose and cortisone was not significant. FR significantly increased plasma albumin compared to the control group, but decreased plasma cholesterol. On the other hand, increasing age of chickens significantly increased plasma albumin, but decreased plasma total protein, globulin, $\mathrm{T}_{3}$ and glucose. There were significant interactions between FR regimen and age of chicks on plasma total protein, albumin and globulin. The control group at d 14 of age showed higher plasma total protein and globulin than the other groups except for total protein of the FR group at $d 35$ of age. However, the contrary trend was observed in the plasma albumin. FR significantly increased plasma albumin (nonspecific immune protein) by $5.3 \%$ compared to the control group, but decreased plasma cholesterol by $3.2 \%$. Serum glucose $(P<0.05)$ and triglyceride $(P<0.001)$ levels decreased at $41 \mathrm{~d}$ of age in broilers fed ad libitum compared to those restricted for $4 \mathrm{~h}$ per day from 7 to $21 \mathrm{~d}$ and fed ad libitum thereafter ${ }^{(20)}$. FR at 12.5 and $25 \%$ of the predicted requirement did not significantly influence Hgb, PCV, serum glucose, total protein, globulin, albumin/globulin ratio goats ${ }^{(40)}$, but decreased serum albumin and urea and improved digestibility of $\mathrm{DM}, \mathrm{OM}, \mathrm{CP}, \mathrm{EE}$ and $\mathrm{ADF}$ and decreased excretion of $\mathrm{N}$ and P. Hepatic leakage (AST and ALT enzymes), muscle catabolism (creatinine) and welfare of chickens (cortisone) at $14 \mathrm{~d}$ (end of restriction period) and $35 \mathrm{~d}$ of age (end of realimentation period) were not affected by FR regimen.

FR group decreased total protein and globulin (specific immune protein) at the termination of the FR period compared to the control group, but increased plasma albumin (nonspecific immune protein and the most favourable source of amino acids for protein synthesis). At the end of the experiment, total protein, albumin and globulin were completely restored. This is connected with lower IgG, HINDV and HIIBD at the termination of the FR period than those at $\mathrm{d} 35$ of age after $21 \mathrm{~d}$ of $\mathrm{ad}$ libitum feeding, which indicates that FR decreased nutrient availability for building up specific immunity and that re-alimentation improved immune system $^{(34)}$. Similarly, plasma total protein and albumin are significantly decreased in either quantitative (fed 85 and $70 \%$ of feed intake by the control group) or qualitative FR (fed 85 and $70 \%$ of the energy control diet). However, at $35 \mathrm{~d}$ of age these blood traits were higher in the qualitative FR groups $^{(36)}$.

FR regimen did not negatively affect liver leakage (AST and ALT enzymes), protein metabolism and renal function (creatinine) and welfare of chickens (cortisone) at 14 (end of restriction period) and $35 \mathrm{~d}$ of age (end of realimentation period) and markers of liver leakage ${ }^{(40)}$. However, a significant changes of corticosterone, $T_{4}$, $T_{3}$, protein, alkaline phosphatase, creatinine kinase in meat type female chickens caused by moderate and severe quantitative FR, illustrating that FR induces an intensive stress during the rapid growth period of fast-growing chicks ${ }^{(41)}$. In addition, plasma levels of both $T_{3}$ and $T_{4}$ were reduced in the FR chicks, and up to $40 \%$ diet dilution decreased cholesterol, triglycerides, plasma $\mathrm{T}_{3}{ }^{(42)}$, but uric acid and plasma $\mathrm{T}_{4}$ increased at $21 \mathrm{~d}$ of age ${ }^{(43)}$. Differences in metabolic profiles and thyroid hormones could be attributed to strain and growth of chickens, duration and intensity of FR.

\section{CONCLUSIONS AND IMPLICATIONS}

Collectively, slow-growing chickens could tolerate $27.2 \%$ of feed restriction during the $7-14 \mathrm{~d}$ of age without significant differences in feed intake, FCR, health status and metabolic profiles at $35 \mathrm{~d}$ of age, showing compensatory growth during $15-35 \mathrm{~d}$ of age.

\section{LITERATURA CITADA}

1 Zhan XA, Wang M, Ren H, Zhao RQ, Li JX, Tan ZL. Effect of early feed restriction on metabolic programming and compensatory growth in broiler chickens. Poult Sci 2007;86:654-660.

2. Saleh K, Attia YA, Younis $H$. Effect of feed restriction and breed on compensatory growth, abdominal fat and some production traits of broiler chicks. Archiv Für Geflügelkunde 1996;60:153-159.

3. Butzen FM, Vieira MM, Kessler AM, Aristimunha PC, Marx FR, Bockor L, Ribeiro A ML. Early feed restriction in broilers. II: Body composition and nutrient gain. J Appl Poult Res 2015;24:198-205.

4. Butzen FM, Ribeiro AML, Vieira MM, Kessler AM, Dadalt JC, Della MP. Early feed restriction in broilers. I- Performance, body fraction weights, and meat quality. J Appl Poult Res 2013;22:251-259.

5. Attia YA, Osman Mona, Abou-Egla El-Samra, El-Deek AA. Response of growth, feed conversion and characteristics of broiler chicks to 
feed restriction methods, time and diet quality. Mansoura Univ. J Agric Sci 1995; 20:3261-3282.

6. Netshipale AJ, Benyi K, Baloyi JJ, Mahlako KT, Mutavhatsindi TF. Responses of two broiler chickens strains to early-age skip-a-day feed restriction in a semi-arid subtropical environment. African J Agr Res 2012; 7:6523-6529.

7. Hassanien HHM, Abdel-Wareth AAA, El-Deek AA. Interaction effects between feed physical form and feed restriction on performance and carcass characteristics of broilers. Egypt. J Anim Prod 2013; 50:19-26.

8. Attia YA, Abd Al-Hamid AE, Ibrahim MS, Al-Harthi M.A, Bovera F, El-Naggar A. Productive performance, biochemical and hematological traits of broiler chicks supplemented with propolis, bee pollen, and mannan oligosaccharides continuously or intermittently. Livestock Sci 2014;164:87-95.

9. Attia YA, Abd- El-Hamid EA, El-Hanoun AM, Al-Harthi MA, Mansour GM, Abdella MM. Responses of the fertility, semen quality, blood constituents, immunity and antioxidant status of rabbit bucks to type and magnetizing of water. Ann Anim Sci 2015; 15:387-407.

10. Young DS, Pestaner CL, Gilberman U. Effects of drugs on clinical laboratory tests. Clin Chem 1975;21:3660-3669.

11. Kawahara E, Ueda T, Nomura S. In vitro phagocytic activity of white spotted shark cells after injection with Aeromonas salmonicida extracelluar products. Gyobyo Kenkyu, Japan 1991;26:213-214.

12. King DJ, Seal BS. Biological and molecular characterization of Newcastle disease virus NDV field isolates with comparisons to reference NDV strains. Avian Dis 1998;42:507-516.

13. Takatsy GY. The use of spiral loops in serological and virological micromethods. Acta Microbiol. Acad Sci Hung 1956;3:197.

14. Cosgrove A. Handbook of histopathological and histochemical staining techniques. 3rd ed., London, UK: Butterworth; 1962.

15. Rainger GE, Rowley AF. Antibacterial activity in the serum and mucus of rainbow trout, Oncorhynchus mykiss following immunization with Aeromonas salmonicida. Fish Shellfish Immunol 1993; 3:475-482.

16. SAS Institute. SAS ${ }^{\circ}$ User's Guide: Statistics. 6th ed., (Cary, NC SAS Institute Inc.), USA. 1996.

17. J unqueira OM, Fonseca LEC, Araújo LF, Duarte KF, Araújo CS. da S. Rodrigues EAP. Feed restriction on performance and blood parameters of broilers fed diets with different sodium levels. Rev Bras Cienc Avic 2003;5:225-230 http://dx.doi.org/10.1590/S1516635X2003000200003.

18. Jalal MAR, Zakaria HA. The effect of quantitative feed restriction during the starter period on compensatory growth and carcass characteristics of broiler chickens. PakJ Nutr 2012;11:719-724.

19. Zubair AK, Leeson S. Compensatory growth in the broiler chickens: a review. World's Poult Sci J 1996;52:189-201.

20. Jahanpour H, Seidavi A, Qotbi AAA, Van Den Hoven R, Rocha e Silva S, Laudadio V, Tufarelli V. Effects of the level and duration of feeding restriction on carcass components of broilers. Arch Anim Breed 2015;58:99-105.

21. Onbaşılar EE, Yalçın S, Torlak E, Özdemir P. Effects of early feed restriction on live performance, carcass characteristics, meat and liver composition, some blood parameters, heterophil-lymphocyte ratio, antibody production and tonic immobility duration. Trop Anim Health Prod 2009;41:1513-1519.

22. Rezaei M, Teimouri AJ, Sayyahzadeh PH, Waldroup PW. Effect of diet dilution in the starter period on performance and carcass characteristics of broiler chicks. J Centr Europ Agri 2006; 7:63-70.

23. Ferrell CL, Koong LJ, Nienaber JA. Effects of previous nutrition on body composition and maintenance energy costs of growing animals. Br J Nutr 1986; 56:595-605.

24. Tumova E, Skrivan M, Skirvanova V, Kacerovska L. Effect of early feed restriction on growth in broiler chickens, turkeys and rabbits. Czech J Anim Sci 2002; 47: 418-428.

25. Sahraei M. Feed restriction in broiler chickens production: A review. Global Veterinaria 2012;8:449-458.

26. Woof J M, Kerr MA. The function of immunoglobulin A in immunity. J Pathol 2006; 208:270-82.

27. J unqueira LC, Carneiro J. Basic histology, USA: McGraw-Hill; 2003. ISBN 0-8385-0590-2.

28. Holmgren J, Czerkinsky C. Mucosal immunity and vaccines. Nature Medicine 2005; 11:S45-S53. doi:10.1038/nm1213. PMID 15812489.

29. Kidd MT. Nutritional modulation of immune function in broilersReview. Poult Sci 2004;83:650-657.

30. Al-Khalifa Hanan, Givens DI, Rymer C, Yaqoob P. Effects of n-3 fatty acids on immune function in broiler chickens. Poult Sci 2012; $91: 74-88$

31. Jang IS, Kang SY, Ko YH, Moon YS, Sohn SH. Effect of qualitative and quantitative feed restriction on growth performance and immune function in broiler chickens. Asian-Aust J Anim Sci 2009;22:388-395.

32. Glick B, Taylor JR, Martin DE, Watabe M, Day EJ, Thompson D. Calorie-protein deficiencies and the immune response of the chickens. II. Cell mediated immunity. Poult Sci 1983;62:1889-1893.

33. Fassbinder-Orth CA, Karasov WH. Effects of feed restriction and realimentation on digestive and immune function in the Leghorn chick. Poult Sci 2006;85: 1449-1456.

34. Mahmood S, Ahmad F, Masood A, Kausar R. Effects of feed restriction during starter phase on subsequent growth performance, dressing percentage, relative organ weights and immune response of broilers. Pak Vet J 2007;27:137-141.

35. Davison TF, Morris TR, Payne LN. Poultry immunology. Poultry Science Symposium Series, CARFAX Publishing Company, Abingdon, England. 1996(24).

36. Zulkifli I, Che Norma MT, Israf DA, Omar AR. The effect of early age feed restriction on subsequent response to high environmental temperatures in female broiler chickens. Poult Sci 2000; 79:1401-1407.

37. Azis A. Performance and heterophil to lymphocyte $(H / L)$ ratio profile of broiler chickens subjected to feeding time restriction. Inter J Poult Sci 2012; 11:153-157.

38. Bovera F, Lestingi A, Piccolo G, Iannaccone F, Attia YA, Tateo A Effect of water restriction on growth performance, feed nutrient digestibility, carcass and meat traits of rabbits. Animal 2013; 7:1600-1606 
Youssef A. Attia, et al. / Rev Mex Cienc Pecu 2017;8(2):175-184

39. Petek M. The effects of feed removal during the day on some production traits and blood parameters of broilers. Turk J Vet Anim Sci 2000;24:447-452.

40. Kumar Sunil, Dutta Narayan, Baliyan S, Pattanaik AK, Singh SK. Effect of feed restriction on nutrient metabolism, metabolic profile and excretion of nutrients in goats. Anim Nutr Feed Technol 2015;15:361-374.

41. Rajman $M$, J uráni $M$, Lamošová $D$, Máčajová $M$, Sedlačková $M$, Košt'ál L, Ježová $D$, Výboh P. The effects of feed restriction on plasma biochemistry in growing meat type chickens ( Gallus gallus).
Comp Bioch Physiol Part A: Molecular \& Integrative physiology 2006; 145:363-371.

42. Ghazanfari S, Kermanshahi H, Nassiry MR, Golian A, Moussavi ARH, Salehi A. Effect of feed restriction and different energy and protein levels of the diet on growth performance and growth hormone in broiler chickens. Inter J Biol Sci 2010; 10:25-30.

43. Rezaei $M$, Hajati $H$. Effect of diet dilution at early age on performance, carcass characteristics and blood parameters of broiler chicks. Italian J Anim Sci 2010;9:e19:93-100. 